\title{
Adsorption of strontium (II) metal ions using phosphonate-functionalized polymer
}

\author{
S M BHOSLE ${ }^{1}$, S PONRATHNAM ${ }^{1}$, S S TAMBE ${ }^{2}$ and N N CHAVAN ${ }^{1, *}$ \\ ${ }^{1}$ Polymer Science and Engineering Division, CSIR-National Chemical Laboratory, Pune 411008, India \\ ${ }^{2}$ Chemical Engineering and Process Development Division, CSIR-National Chemical Laboratory, Pune 411008, India
}

MS received 28 October 2015; accepted 5 April 2016

\begin{abstract}
Diethyl[3-(methoxydimethylsilyl)propyl]phosphonate (DMPP) polymer was synthesized for the strontium (II) metal ion recovery using diethylallylphosphonate as staring material. Diethylallylphosphonate was reacted with poly(methylhydro)siloxane (MW $1900-2000 \mathrm{~g} \mathrm{~mol}^{-1}$ ) in the presence of Speier's catalyst. The synthesized monomer was characterized by IR, ${ }^{1} \mathrm{H}$ NMR, ${ }^{13} \mathrm{C}$ NMR and FT-IR spectroscopy techniques, and the synthesized polymers were characterized by IR and NMR spectroscopy, differential scanning calorimetry, thermogravimetric analysis and solubility. The synthesized polymer was used for sequestering strontium metal from the aqueous solution. The metal binding was examined by the energy dispersive spectroscopy and scanning electron microscopy for the adsorbed $\mathrm{Sr}$ (II). Batch adsorption studies were performed by varying three parameters, namely initial pH, adsorbent dose and the contact time. The reaction kinetics was determined by the Langmuir, Freundlich, and pseudo-firstand second-order models. Results of this study indicate that the synthesized polymer DMPP has been effective in removing $\operatorname{Sr}(\mathrm{II})$ from the aqueous solution.
\end{abstract}

Keywords. Phosphonate polymer; metal; strontium; EDX; SEM; pH.

\section{Introduction}

Chelation is a process wherein metalions and a polymer/matrix are bound together by a chelating agent. A ligand can donate electrons to an electron-deficient metal atom to form a complex. The chelating agent contains at least two electron donating atoms. It is composed of the donor atoms that are connected by the intramolecular chains of other atoms; a chelate ring is formed for each donor atom, followed by the coordination with the metal ion. A chelate is a complex chemical compound composed of a metal ion and a chelating agent, whose molecules form several bonds to a single metal ion. The chelate-producing polymeric ligands are formed by the reactive oxygen, nitrogen, sulphur and phosphorus donor atoms, capable of coordinating with different metal ions. Introducing phosphonate group into a polymer has many applications, such as, flame retardation, stabilizer for peroxides, pesticides and metal ion sequestration.

Being stable, persistent, non-degradable and indestructible, the heavy metal ions in the water resources are a major cause of concern today. Standard techniques are routinely used to decontaminate the liquid waste streams. Various technologies used for the wastewater treatment include filtration, precipitation, ion exchange, adsorption, membrane separation process, electrochemical techniques and chemical reactions. Each one of these processes has merits and

*Author for correspondence (nn.chavan@ncl.res.in) drawbacks. The extent to which the stated technologies are used individually and in combination depends on the amount and source of the contamination. There are four main technologies for the treatment of the liquid waste: evaporation, chemical precipitation/flocculation, solid-phase separation and ion exchange [1,2]. Among these, adsorption is a more selective and low-cost method; both these attributes are advantageous.

The radioactive strontium occurs in the environment as ${ }^{89} \mathrm{Sr}$ and ${ }^{90} \mathrm{Sr}$ with half-lives of 51 days and 29 years, respectively. It is produced not only as a waste fission product from nuclear power plants, but also produced in the reprocessing of nuclear fuels [3]. The 1986 Chernobyl nuclear accident contaminated a vast area with ${ }^{90} \mathrm{Sr}$. The radioactive ${ }^{90} \mathrm{Sr}$ can lead to various bone disorders and diseases including bone cancer. The lightest isotope of the radioactive strontium is ${ }^{73} \mathrm{Sr}$ and the heaviest being ${ }^{107} \mathrm{Sr}$ [4]. The risk from the intake of radioactive strontium arises mainly due to its carcinogenic and mutagenic properties. Thus, the development of efficient and effective methodologies for the removal of these toxic metal ions from the water bodies forms an important research activity. It is necessary to remove strontium from the waste streams before it is discharged to the environment. ${ }^{90} \mathrm{Sr}$ is considered as one of the most hazardous element in the fission product. Accordingly, this article reports the results of a number of adsorption kinetic studies for the removal of strontium ions from the wastewater. Specifically, we have studied the synthesis, characterization and strontium metal ion adsorption 
using diethyl[3-(methoxydimethylsilyl)propyl]-phosphonate (DMPP) polymer. The effect of various reaction parameters, such as $\mathrm{pH}$, contact time and polymer concentration, on the adsorption performance of the polymer has been rigorously investigated [5-9].

The diethylallylphosphonate monomer was synthesized by Michaelis-Arbuzov reaction [10] using allyl bromide and triethylphosphite. A number of procedures for the synthesis of phosphonate diester are described in the literature [11-17]. The Michaelis-Arbuzov reaction (also termed Arbuzov reaction) is the most versatile pathway for the formation of carbonphosphorus bond, which involves reaction of an ester of trivalent phosphorus with alkyl or allyl halide $[18,19]$.

A wide range of catalysts including AIBN, which is very common in many free radical polymerization reactions [20]; gold nanoparticles, used as an active catalyst for breaking the double bond of alkene [21]; and other simple catalysts such as pd, pt, Lewis acids (such as $\mathrm{AlCl}_{3}, \mathrm{HfCl}_{4}, \mathrm{EtAlCl}_{2}$, $\mathrm{ZrCl}_{4}$ and $\mathrm{TiCl}_{4}$ ), $\mathrm{Rh}$ and $\mathrm{Ru}$ are used in hydrosilylation reaction [22-30]. Hydrosilylation reaction is very important for preparing silane-based polymers. Among all the catalysts, effective, active and selective is platinum-based catalystwhich was found to be most suitable for hydrosilylation [31]. In this testing, the Speier's catalyst was used-which is nothing but a solution of hexachloroplatinic acid in 2-isopropanol (1-10\%) and is referred to as the Speier's catalyst, the most widely used platinum catalyst [32]. Hydrosilanes undergo addition across the carbon-carbon multiple bonds with Speier's catalysis effected by the transition metal complexes. The hydrosilylation mechanism is explained by Chalk-Harrod [33]. A number of studies exist wherein the said mechanism has been employed to synthesize polymers [34,35].

This article describes the synthesis of DMPP polymer for the removal of strontium metal from an aqueous solution. Phosphonate-functionalized polymers are highly effective for the sequestration of strontium (II) metal ions; therefore, the phosphonate-based polymers have been explored for the extraction of strontium metal ions. This study focuses on the adsorption of strontium [Sr(II)] from the strontium nitrate solution using a laboratory-synthesized polymer, wherein the strontium uptake has been examined by scanning electron microscopy (SEM) and energy dispersive spectroscopy (EDS) [36].

\section{Materials and methods}

Allyl bromide was procured from Spectrochem, whereas triethylphosphite was sourced from Aldrich. Poly(methylhydro) siloxane (MW 1900-2000 $\mathrm{g} \mathrm{mol}^{-1}$ ) was sourced from Gelest Ltd. Hexachloroplatinic acid, potassium chloride, acetic acid, sodium acetate trihydrate and tris(hydroxymethyl)aminomethane were obtained from Loba Chemie. Toluene, 2-propanol, strontium nitrate and hydrochloric acid were obtained from Merck.

\subsection{Synthesis of monomer diethylallylphosphonate}

A two-necked round-bottom flask was equipped with a reflux condenser, magnetic stirrer and nitrogen inlet. The reaction vessel was charged with triethylphosphite $(10 \mathrm{~g}, 0.06 \mathrm{~mol})$ and allyl bromide $(6.06 \mathrm{~g}, 0.07 \mathrm{~mol})$ was added to it dropwise. As soon as the reaction mixture became homogeneous, it was refluxed under continuous stirring at $120^{\circ} \mathrm{C}$ for $24 \mathrm{~h}$. After completion of the reaction, the mixture was allowed to cool to room temperature. Next, the reaction mixture was concentrated and excess triethylphosphite and allyl bromide were removed under reduced pressure. The product was formed with $75 \%$ yield (based on the charged allyl bromide). The reaction was monitored by thin layer chromatography (TLC) using 60\% ethyl acetate in petroleum ether as eluent.

\subsection{Synthesis of phosphonate-functionalized polymer}

A $50 \mathrm{ml}$ round-bottom flask was fitted with a reflux condenser, magnetic stirred and nitrogen inlet. This reaction vessel was charged with diethylallylphosphonate $(2 \mathrm{~g}, 1.19 \mathrm{~mol})$, poly(methylhydro)siloxanes $(1.2 \mathrm{~g}, 1.14 \mathrm{~mol})$ and $8 \mathrm{ml}$ of toluene. The mixture was kept under stirring at room temperature. As soon as the mixture became homogeneous, $1 \mathrm{ml}$ of Speier catalyst ( $2 \mathrm{wt} \%$ solution of hexachloroplatinic acid $\left(\mathrm{H}_{2} \mathrm{PtCl}_{6}-6 \mathrm{H}_{2} \mathrm{O}\right)$ in 2-propanol) was added to it dropwise over a period of $30 \mathrm{~min}$ at room temperature. Bubble formation began instantaneously in the reaction mixture and was maintained during the stirring for $30 \mathrm{~min}$ at room temperature. Next, the reaction mixture was refluxed with stirring at $120^{\circ} \mathrm{C}$ for $12 \mathrm{~h}$. Thereafter, it was allowed to cool to room temperature, following which toluene was evaporated on a rotavapor and extracted in chloroform. The organic layer was washed with water, dried over sodium sulphate, and the solvent was removed on rotavapor. The compound was dried under reduced pressure at $60^{\circ} \mathrm{C}$ for $6 \mathrm{~h}$, resulting in a viscous dark brown coloured product. Monitoring of the reaction was done by TLC using $60 \%$ ethyl acetate in petroleum ether as an eluent. The product yield was determined to be $55 \%$, based on the charged diethylallylphosphonate.

\subsection{Preparation of buffer solutions}

2.3a Preparation of buffer solution $p H$ 1: Stock solution of buffer at $\mathrm{pH} 1$ was prepared by dissolving $0.2 \mathrm{M} 100 \mathrm{ml}$ of potassium chloride in $0.2 \mathrm{M} 220 \mathrm{ml}$ of hydrochloric acid.

2.3b Preparation of buffer solution $\mathrm{pH}$ 3: Stock solution of buffer at $\mathrm{pH} 3$ was prepared by dissolving $0.1 \mathrm{M} 25 \mathrm{ml}$ of acetic acid in $0.1 \mathrm{M} 0.450 \mathrm{ml}$ of sodium acetate trihydrate.

2.3c Preparation of buffer solution $p H$ 5: Stock solution of buffer at $\mathrm{pH} 5$ was prepared by dissolving $0.1 \mathrm{M} 357 \mathrm{ml}$ of acetic acid in $0.1 \mathrm{M} 643 \mathrm{ml}$ of sodium acetate trihydrate. 
2.3d Preparation of buffer solution $p H$ 7: Stock solution of buffer at $\mathrm{pH} 7$ was prepared by dissolving $0.1 \mathrm{M} 100 \mathrm{ml}$ of tris(hydroxymethyl)aminomethane in $0.1 \mathrm{M} 93.2 \mathrm{ml}$ of hydrochloric acid.

\subsection{Batch adsorption study}

2.4a Effect of $\mathrm{pH}$ : The $\mathrm{pH}$ of the solution has been identified as one of the most important parameters affecting the sorption of metal ions. Accordingly, the effect of the solution $\mathrm{pH}$ on the adsorption capacity of DMPP polymer was investigated by using buffer solutions of $\mathrm{pH}$ magnitudes of $1,3,5$ and 7 ; in these experiments, strontium nitrate solution of concentration $5 \mathrm{mg} \mathrm{ml}^{-1}$ was used and the adsorption was carried out at room temperature for $24 \mathrm{~h}$. Sorption equilibrium was attained during this time, after which the supernatant solution was filtered and the concentration of strontium adsorbed (in \%) on the polymer was determined by EDS.

2.4b Effect of contact time: In order to compare the adsorption capability of the composite adsorbent, the effect of contact time on the adsorption of $\mathrm{Sr}$ (II) was investigated at room temperature. For this, a stock solution of strontium nitrate was prepared by dissolving $125 \mathrm{mg}$ of strontium nitrate in $25 \mathrm{ml}$ of $\mathrm{pH} 3$ buffer solution.

2.4c Effect of polymer concentration: The maximum strontium uptake was investigated over a period of $24 \mathrm{~h}$ at room temperature by varying the concentration of the polymer. This study was conducted using a stock solution of strontium nitrate prepared by dissolving $200 \mathrm{mg}$ of strontium nitrate in $10 \mathrm{ml}$ of $\mathrm{pH} 3$ buffer solution.

\subsection{Characterization}

${ }^{1} \mathrm{H}$ and ${ }^{31} \mathrm{P}$ NMR spectra were recorded on a Bruker AC400 instrument using a deuterated solvent $\left(\mathrm{CDCl}_{3}\right)$ and tetramethylsilane as the reference; chemical shifts are given in hertz $(\mathrm{Hz})$. Fourier transform infrared spectroscopy (FT-IR; Model 68 B, Perkin Elmer, USA) was used to identify the functional groups present in the structure of monomers and polymers. The samples were prepared in acetone. Thermal properties were determined by differential scanning calorimetry (DSC) using TA Q100 instrument under nitrogen atmosphere at the heating rate of $10^{\circ} \mathrm{C} \mathrm{min}^{-1}$. All samples were run against an aluminium reference in crimped $\mathrm{Al}$ pans. The weight of the sample was in the range 3-9 $\mathrm{mg}$. A temperature range of -50 to $120^{\circ} \mathrm{C}$ was used to determine the glass transition temperature $\left(T_{\mathrm{g}}\right)$ of hydrogen-bond acidic polymers. A second heating cycle was used for the assessment of $T_{\mathrm{g}}$, defined as the inflection point in the heat capacity jump.

The thermal stability of the copolymer was studied by the thermogravimetric analysis (TGA) instrument (STA 6000 from Perkin Elmer). The sample was heated at the rate of $10^{\circ} \mathrm{C} \mathrm{min}^{-1}$ under nitrogen atmosphere in the temperature range of $30-900^{\circ} \mathrm{C}$. For elemental analysis (chemical characterization) of a sample, an analytical technique termed energy-dispersive X-ray spectroscopy (EDS) was used; this analysis was carried out using D451-10C energy dispersive X-ray spectroscopy (Quantax-200) with X-flash LN2 free detector (model 4010). Contact angle was measured by 'KRUSS' Thermostat Chamber TC3010/3410 using Drop Shape Analysis Systems G2, G10 and DSA10. SEM was used to obtain information about the sample's surface topography and composition. This analysis was performed using an SEM Model Leica-streoscan 440 by M/S Leica Cambridge Ltd, with an attachment of New EDS D451-10C; here, $\mathrm{pH}$ of the solution was determined by the $\mathrm{pH}$ Cyberscan 510, EUTECH instrument.

Surface area was determined with BET (BrunauerEmmett-Teller) method using Quantachrome Nova 2000E Instrument, USA. All the samples were evacuated at $65^{\circ} \mathrm{C}$.

\section{Results and discussion}

The synthetic pathways of monomer and polymer are shown in Schemes 1 and 2, respectively.

\subsection{Nuclear magnetic resonance}

In the ${ }^{1} \mathrm{H}$ NMR spectrum $\left(\mathrm{CDCl}_{3}, \delta\right.$ p.p.m.) of the monomer diethylallylphosphonate (figure 1), a triplet is obtained at 1.20 p.p.m. assigned to two $-\mathrm{CH}_{3}$ groups. The doublet of a doublet observed at 2.45 to 2.61 p.p.m. was assigned to the allylic $-\mathrm{CH}_{2}$ protons. The quartet observed at 3.964.10 p.p.m. is attributed to two ethylene $-\mathrm{CH}_{2}$ protons attached to the phosphonate groups. While the multiplate observed at 5.08-5.16 p.p.m. be assigned to the allylic $=\mathrm{CH}_{2}$ protons, the one observed at 5.6-5.8 p.p.m. attributed to the allylic $=\mathrm{CH}-$ protons.

The ${ }^{1} \mathrm{H}$ NMR spectrum (figure 2) of DMPP polymer shows a singlet peak at 0.0 p.p.m. assigned to the $-\mathrm{SiCH}_{3}$ group; a multiplate observed at 1.10 p.p.m. was assigned to two methylene groups $\left(-\mathrm{Si}-\mathrm{CH}_{2}-\mathrm{CH}_{2}-\right)$. The triplate observed at 1.21 p.p.m. was assigned to two $-\mathrm{CH}_{3}$ groups. While the peak at 1.55 p.p.m. was assigned to $-\mathrm{Si}-\mathrm{CH}_{2}$, the one at 3.98 p.p.m. was assigned to two ethylene $-\mathrm{CH}_{2}$ protons attached to the phosphonate group.

In the ${ }^{31} \mathrm{P}$ NMR spectrum of the monomer diethylallylphosphonate (figure 3), a peak was observed at 31.16 p.p.m., which indicates the presence of the phosphorous atom.

The presence of this atom is also indicated by the peak at 31.71 p.p.m. in the ${ }^{31} \mathrm{P}$ NMR spectrum of the polymer DMPP (figure 4).

\subsection{FT-IR}

The occurrence of the specific functional groups in the monomer and polymer were confirmed by FT-IR spectroscopy. IR $\left(\mathrm{cm}^{-1}\right)$ spectrum of monomer (figure 5) shows 


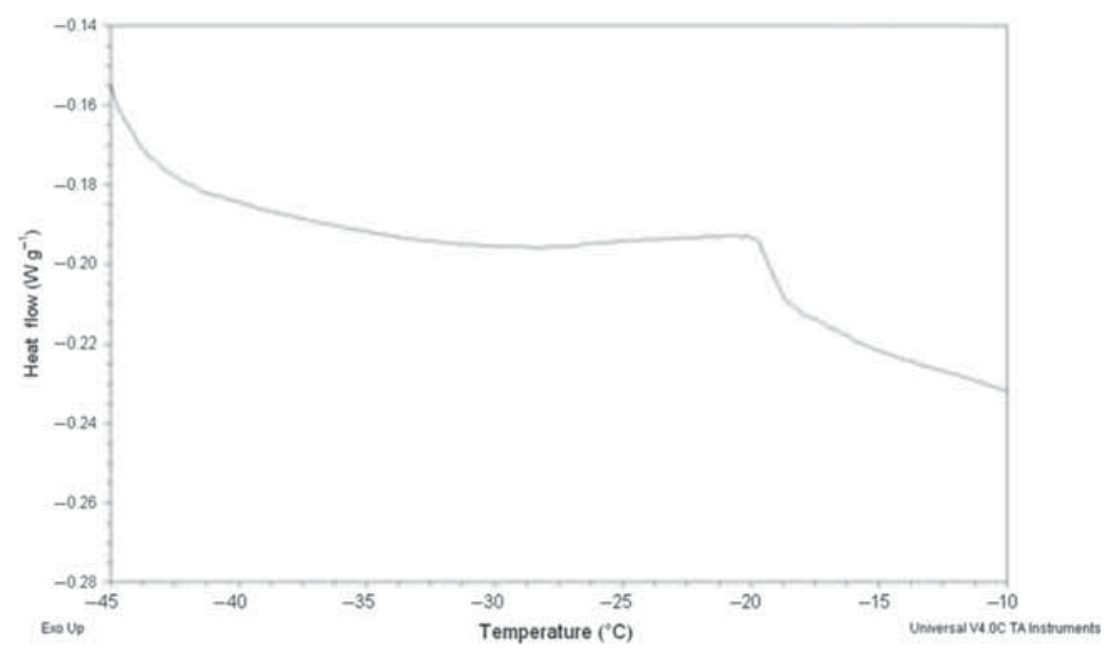

Scheme 1. Synthesis of monomer [diethylallylphosphonate].

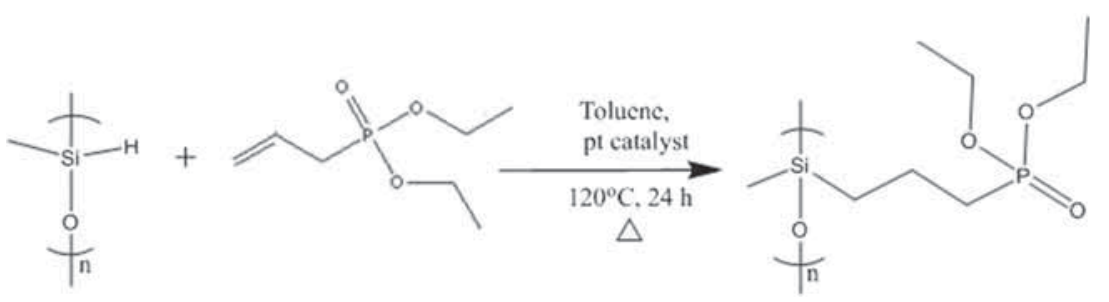

Scheme 2. Synthesis of polymer [diethyl[3-(methoxydimethylsilyl)propyl]phosphonate].

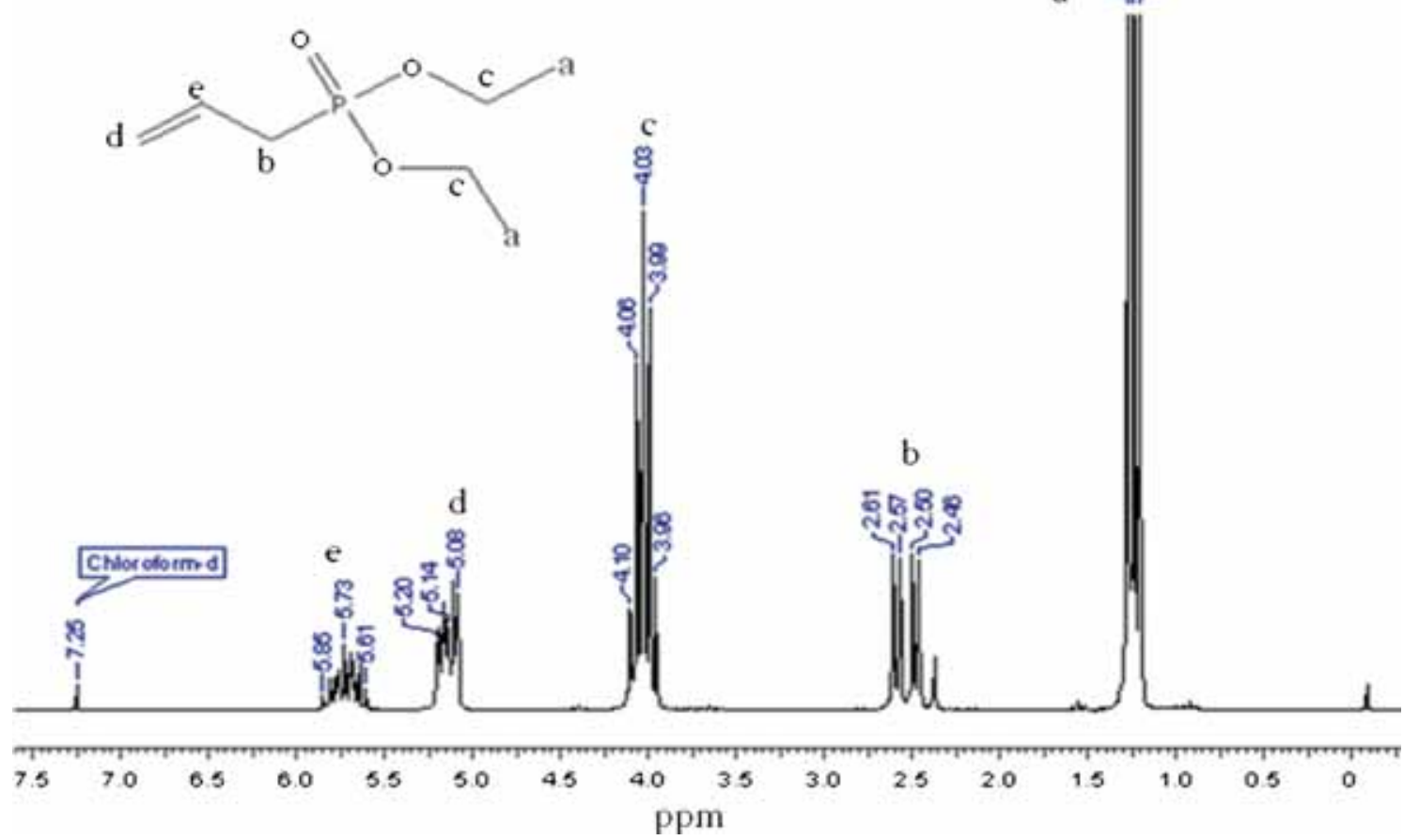

Figure 1. ${ }^{1} \mathrm{H}$ NMR spectrum of diethylallylphosphonate. 
<smiles>CCOP(=O)(CCC[Si](C)(C)OC(C)(C)C)OCC</smiles>
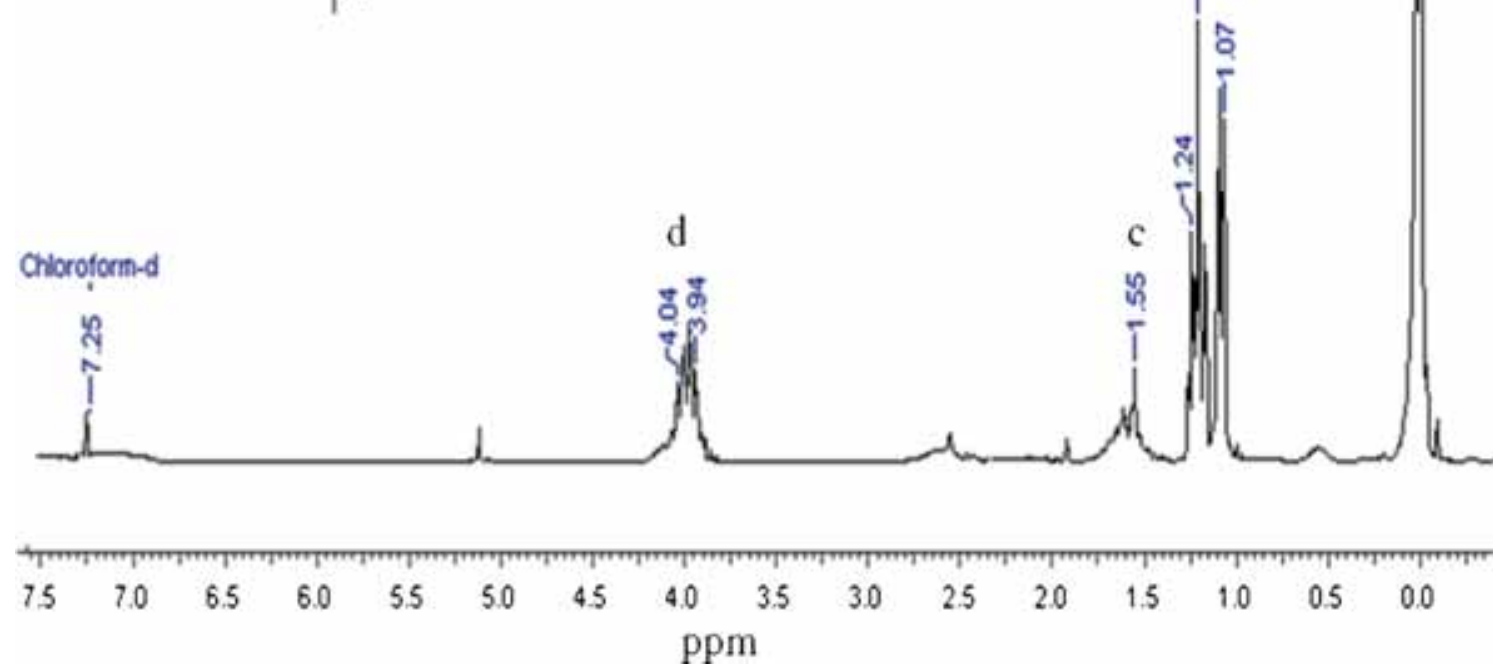

Figure 2. $\quad{ }^{1} \mathrm{H}$ NMR spectrum of polymer DMPP.

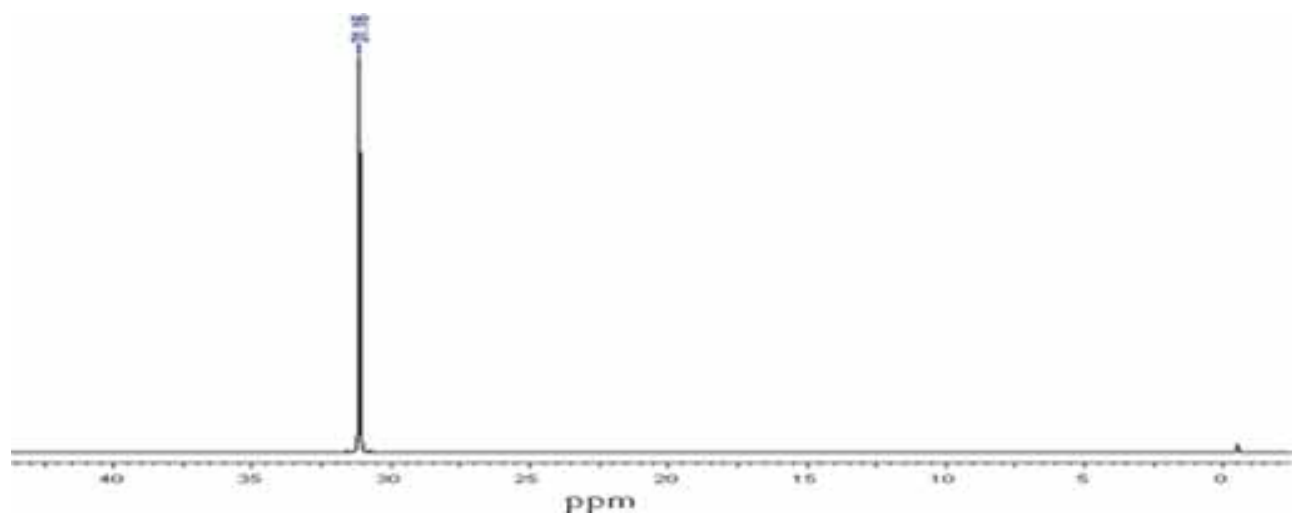

Figure 3. ${ }^{31} \mathrm{P}$ NMR spectrum of diethylallylphosphonate.

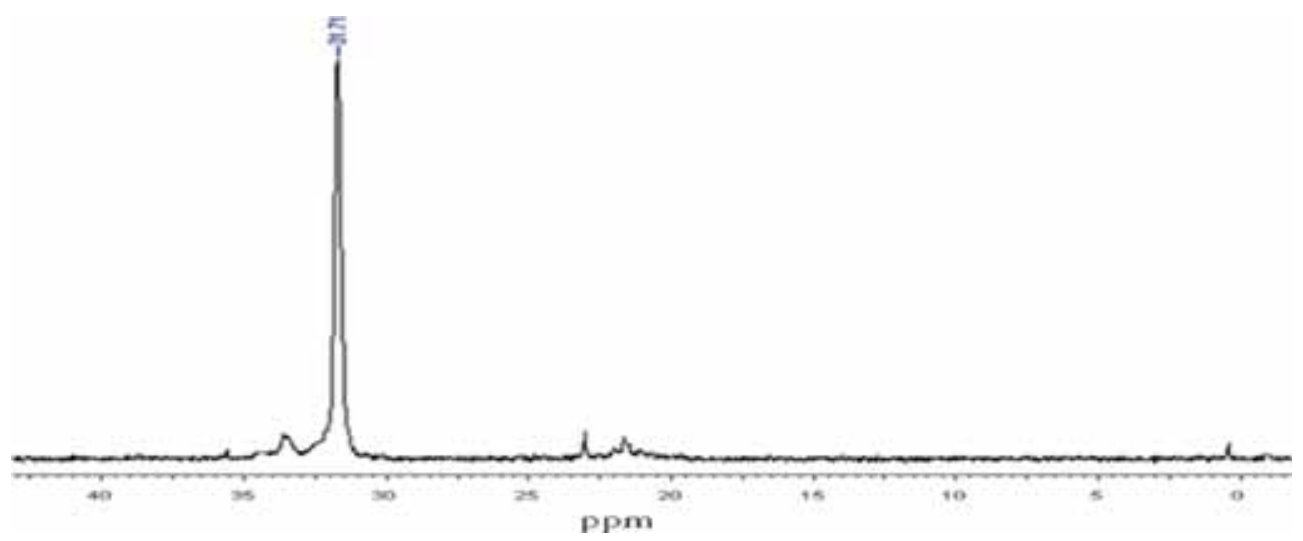

Figure 4. ${ }^{31} \mathrm{P}$ NMR spectrum of polymer of DMPP. 


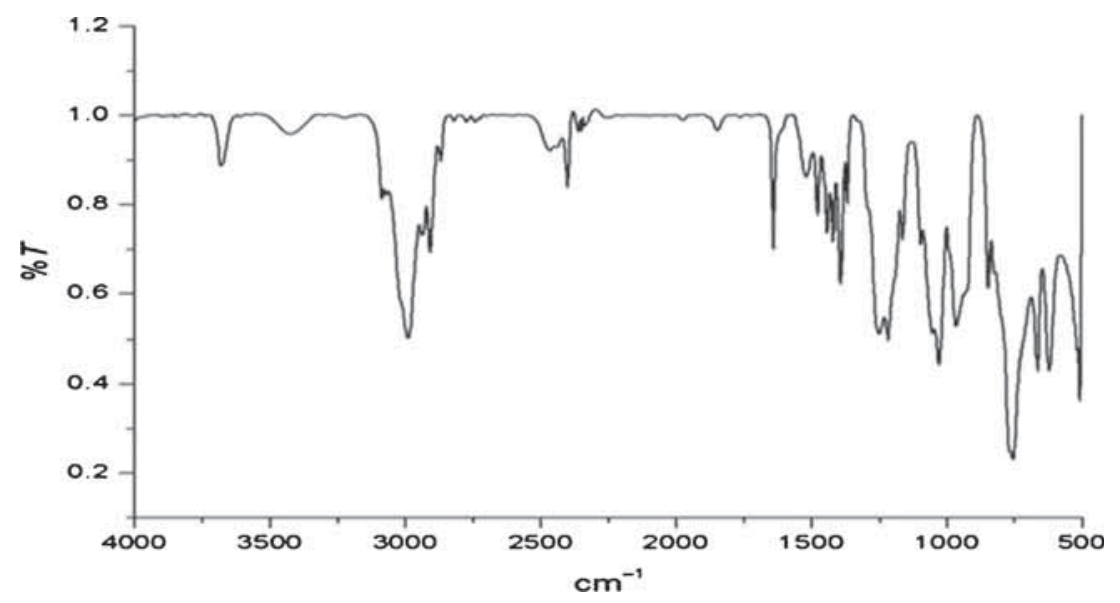

Figure 5. FT-IR spectrum of diethylallylphosphonate.

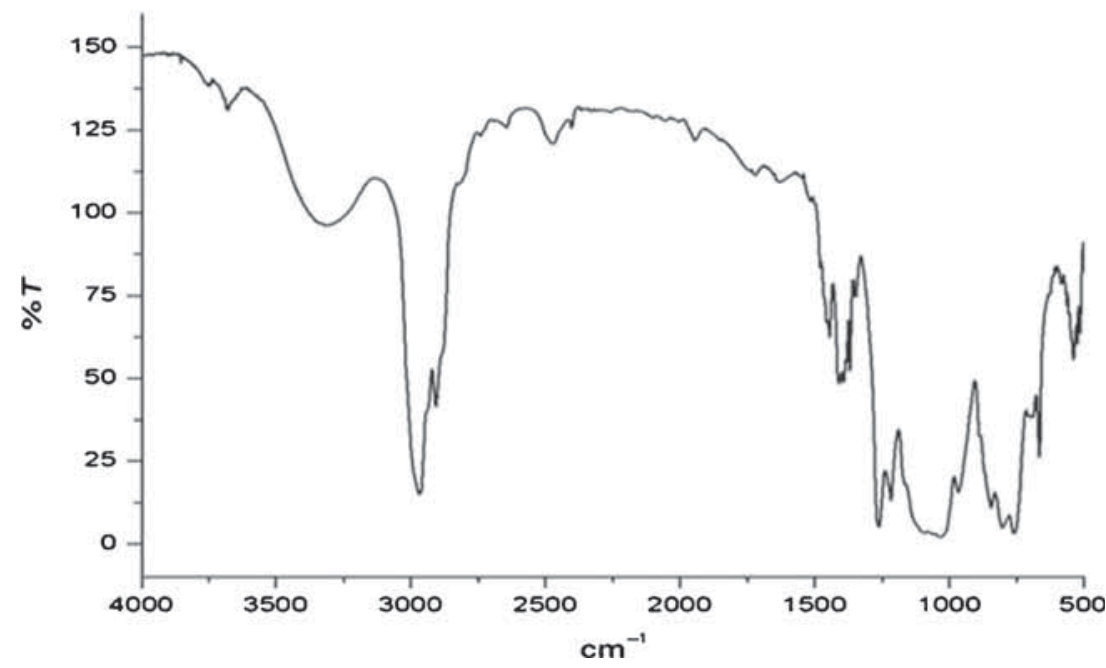

Figure 6. FT-IR spectrum of DMPP.

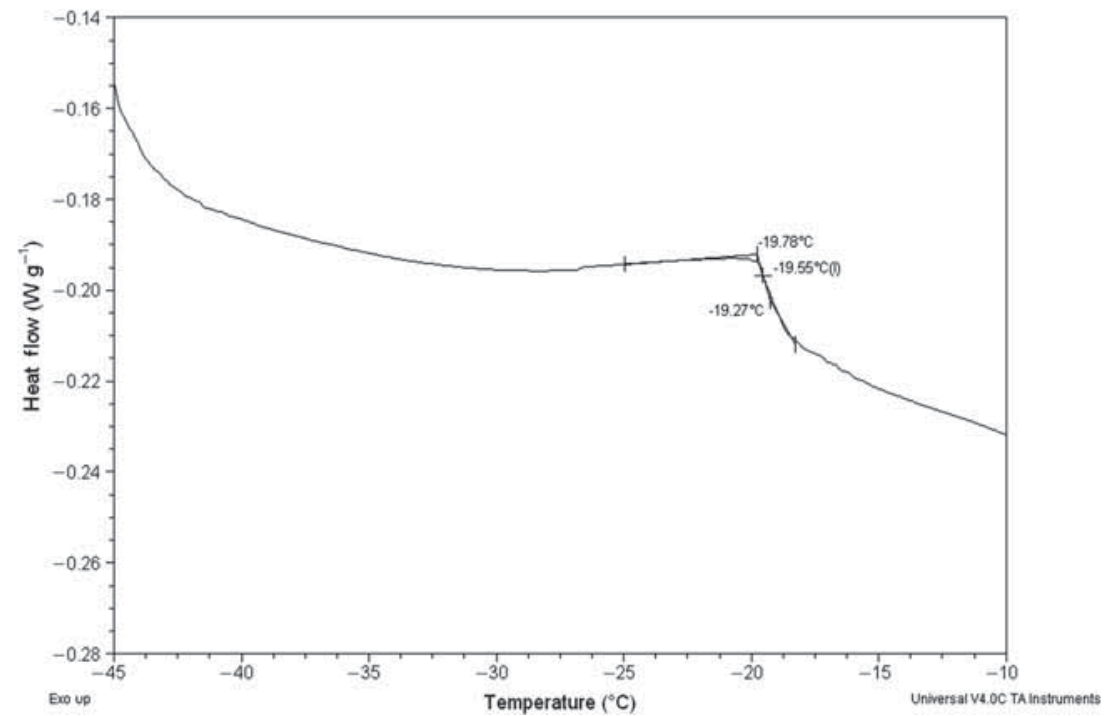

Figure 7. DSC thermogram of DMPP. 
the presence of $-\mathrm{O}-\mathrm{CH}_{2}$ group at $1050 \mathrm{~cm}^{-1}, \mathrm{P}=\mathrm{O}$ group at $1253 \mathrm{~cm}^{-1},-\mathrm{CH}_{2}-\mathrm{P}=\mathrm{O}$ groups at $1393 \mathrm{~cm}^{-1}$ and $-\mathrm{CH}$ bending at $1369 \mathrm{~cm}^{-1}$. The strong peak at $1640 \mathrm{~cm}^{-1}$ indicates the presence of allylic group, while the stretched peak at $2983 \mathrm{~cm}^{-1}$ corresponds to $-\mathrm{CH}$ stretching.
In IR spectra $\left(\mathrm{cm}^{-1}\right)$ of polymer DMPP (figure 6), no $\mathrm{Si}-\mathrm{H}$ peak is observed in $2100-2250 \mathrm{~cm}^{-1}$ range. Allylic group peak appeared at $1640 \mathrm{~cm}^{-1}$. It is however observed that the peaks pertaining to the phosphonate and $\mathrm{Si}-\mathrm{CH}_{3}$ functional groups appeared at 1262 and $849 \mathrm{~cm}^{-1}$, respectively.

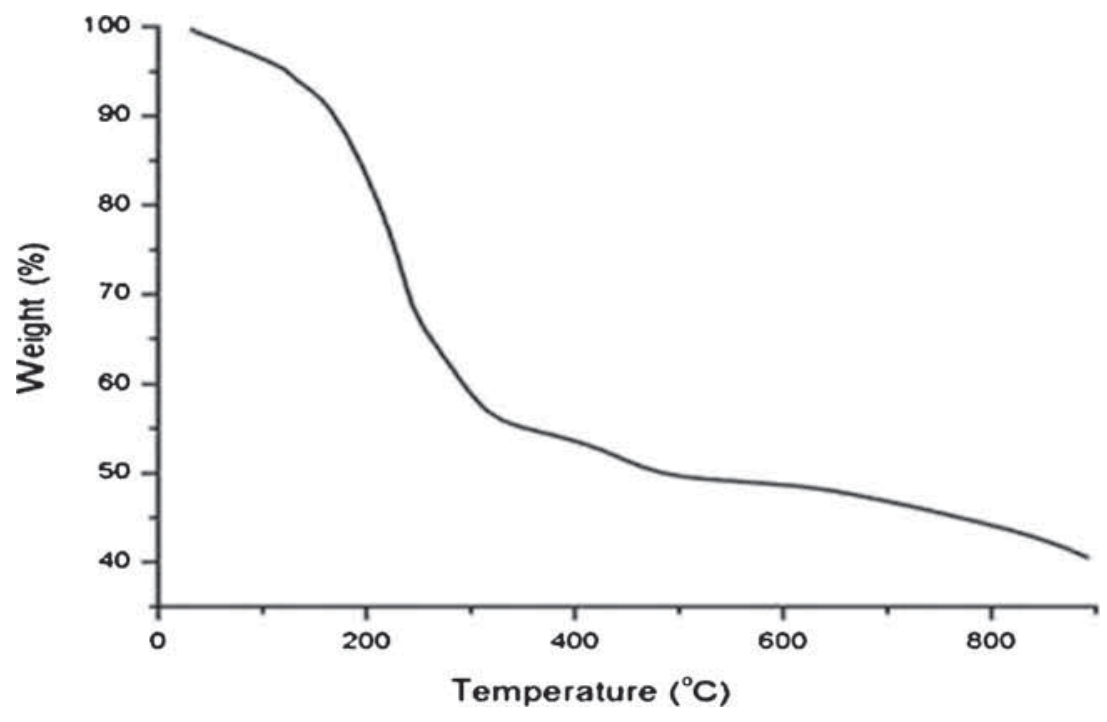

Figure 8. TGA thermogram of polymer of DMPP.
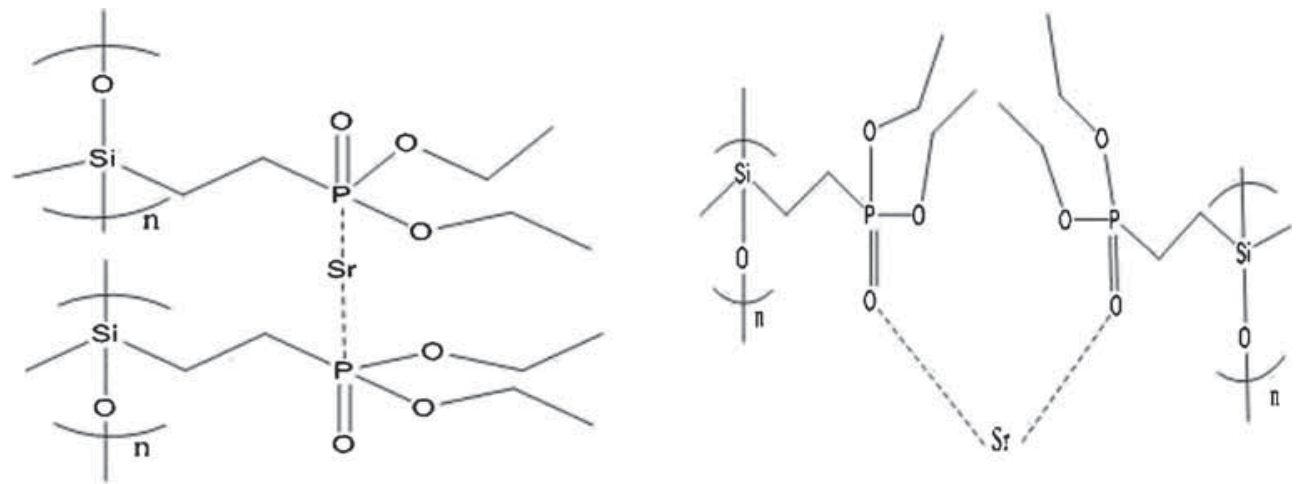

Figure 9. Effective interaction between strontium and DMPP.

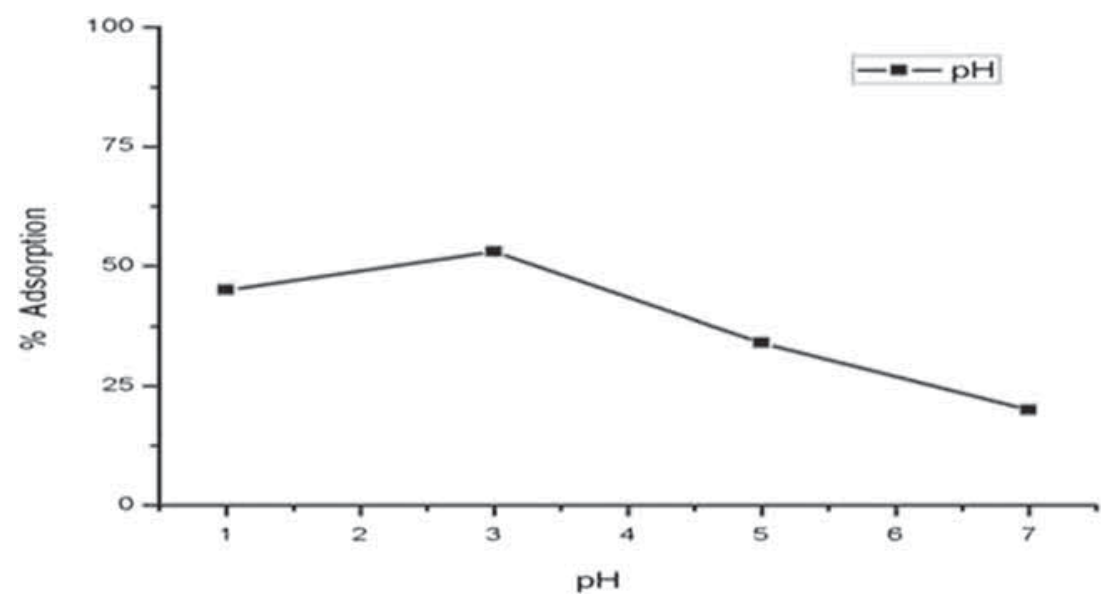

Figure 10. Effect of $\mathrm{pH}$ on strontium adsorption. 


\subsection{Differential scanning calorimetry}

Figure 7 shows the glass transition temperature $\left(T_{\mathrm{g}}\right)$ of polymer of DMPP at $-19^{\circ} \mathrm{C}$.

\subsection{Thermogravimetric analysis}

The thermal stability of diethyl[3-(methoxydimethylsilyl)propyl]-phosphonate polymer was measured by TGA. TGA thermogram is shown in figure 8 and was observed that the polymer is stable up to $280^{\circ} \mathrm{C}$.

\subsection{Solubility}

Solubility of the polymer DMPP was checked in different solvents and it was found that the polymer is soluble in methanol, chloroform, tetrahydrofuran, ethylacetate, methylisobutylketone and acetone.

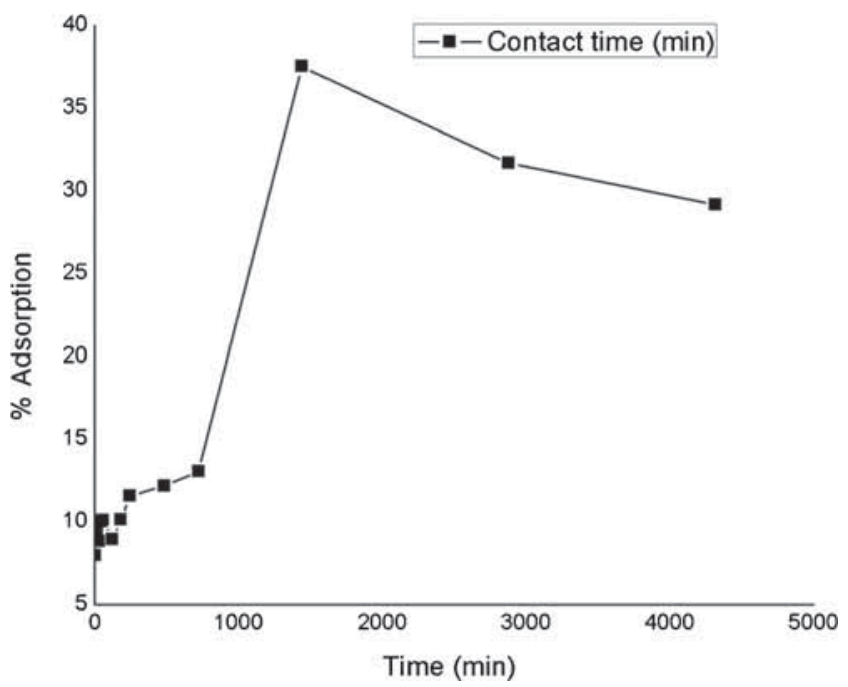

Figure 11. Effect of contact time on strontium adsorption.

Table 1. Effect of $\mathrm{pH}$ on strontium adsorption.

\begin{tabular}{lcccc}
\hline $\begin{array}{l}\text { Polymer } \\
\text { concentration } \\
(\mathrm{mg})\end{array}$ & $\begin{array}{c}\text { Metal } \\
\text { concentration } \\
(\mathrm{ml})\end{array}$ & $\mathrm{pH}$ & $\begin{array}{c}\text { Sr adsorbed } \\
\text { by EDX } \\
\text { (at. wt\%) }\end{array}$ & $\begin{array}{c}\text { Sr recovery } \\
\text { (at. wt\%) }\end{array}$ \\
\hline 5 & 1 & 1 & 3.92 & 45.74 \\
5 & 1 & 3 & 4.27 & 53.46 \\
5 & 1 & 5 & 2.98 & 34.77 \\
5 & 1 & 7 & 1.72 & 20.05 \\
\hline
\end{tabular}

Note: a, DMPP; b, strontium nitrate.

Table 2. Repetition experiments on effect of $\mathrm{pH}$ on strontium adsorption.

\begin{tabular}{lccccc}
\hline $\begin{array}{l}\text { Polymer } \\
\text { concentration } \\
(\mathrm{mg})\end{array}$ & $\begin{array}{c}\text { Metal } \\
\text { concentration } \\
(\mathrm{ml})\end{array}$ & $\mathrm{pH}$ & $\begin{array}{c}\text { Sr recovery } \\
\text { first repetition } \\
\text { (at. wt\%) }\end{array}$ & $\begin{array}{c}\text { Sr recovery } \\
\text { second repetition } \\
\text { (at. wt\%) }\end{array}$ & $\begin{array}{c}\text { Sr recovery } \\
\text { third repetition } \\
\text { (at. wt\%) }\end{array}$ \\
\hline 5 & 1 & 1 & 45.74 & 30.61 & 20.58 \\
5 & 1 & 3 & 53.46 & 64.15 & 34.62 \\
5 & 1 & 5 & 34.77 & 43.63 & 29.99 \\
5 & 1 & 7 & 20.05 & 18.07 & 25.49 \\
\hline
\end{tabular}

Table 3. Graphical presentation of effect of $\mathrm{pH}$ on strontium adsorption.

$\begin{gathered}\text { Sr recovery first } \\ \text { repetition (at. wt\%) }\end{gathered}$
$\begin{gathered}\text { Sr recovery second } \\ \text { repetition (at. wt\%) }\end{gathered}$


Table 4. Effect of contact time on strontium adsorption.

\begin{tabular}{lcccc}
\hline $\begin{array}{l}\text { Polymer } \\
\text { concentration } \\
(\mathrm{mg})\end{array}$ & $\begin{array}{c}\text { Metal } \\
\text { concentration } \\
(\mathrm{ml})\end{array}$ & $\begin{array}{c}\text { Contact time } \\
(\mathrm{min})\end{array}$ & $\begin{array}{c}\text { Sr adsorbed by } \\
\text { EDX } \\
\text { (at. wt\%) }\end{array}$ & $\begin{array}{c}\text { Sr } \\
\text { recovery } \\
\text { (at. wt\%) }\end{array}$ \\
\hline 5 & 1 & 0005 & 02.34 & 7.99 \\
5 & 1 & 0015 & 02.76 & 09.42 \\
5 & 1 & 0030 & 02.58 & 08.81 \\
5 & 1 & 0045 & 02.93 & 10.01 \\
5 & 1 & 0060 & 02.96 & 10.11 \\
5 & 1 & 0120 & 02.62 & 08.95 \\
5 & 1 & 0180 & 02.97 & 10.14 \\
5 & 1 & 0240 & 03.39 & 11.58 \\
5 & 1 & 0480 & 03.57 & 12.19 \\
5 & 1 & 0720 & 03.83 & 13.08 \\
5 & 1 & 1440 & 10.98 & 37.51 \\
5 & 1 & 2880 & 09.27 & 31.67 \\
5 & 1 & 4320 & 08.54 & 29.17 \\
\hline
\end{tabular}

Table 5. Repetition experiments on effect of contact time on strontium adsorption.

\begin{tabular}{lccccc}
\hline $\begin{array}{l}\text { Polymer } \\
\text { concentration } \\
(\mathrm{mg})\end{array}$ & $\begin{array}{c}\text { Metal } \\
\text { concentration } \\
(\mathrm{ml})\end{array}$ & $\begin{array}{c}\text { Contact } \\
\text { time } \\
(\mathrm{min})\end{array}$ & $\begin{array}{c}\text { Sr recovery } \\
\text { first repetition } \\
\text { (at. wt\%) }\end{array}$ & $\begin{array}{c}\text { Sr recovery } \\
\text { second repetition } \\
\text { (at. wt\%) }\end{array}$ & $\begin{array}{c}\text { Sr recovery } \\
\text { third repetition } \\
\text { (at. wt\%) }\end{array}$ \\
\hline 5 & 1 & 0005 & 07.99 & 03.92 & 05.62 \\
5 & 1 & 0015 & 09.42 & 07.13 & 08.59 \\
5 & 1 & 0030 & 08.81 & 08.26 & 08.21 \\
5 & 1 & 0045 & 10.01 & 06.35 & 09.99 \\
5 & 1 & 0060 & 10.11 & 08.88 & 10.05 \\
5 & 1 & 0120 & 08.95 & 08.11 & 09.60 \\
5 & 1 & 0180 & 10.14 & 09.61 & 09.69 \\
5 & 1 & 0240 & 11.58 & 10.12 & 10.15 \\
5 & 1 & 0480 & 12.19 & 09.87 & 11.84 \\
5 & 1 & 0720 & 13.08 & 08.66 & 12.39 \\
5 & 1 & 1440 & 37.51 & 22.89 & 34.66 \\
5 & 1 & 2880 & 31.67 & 14.41 & 21.47 \\
5 & 1 & 4320 & 29.17 & 15.09 & 20.77 \\
\hline
\end{tabular}

Table 6. Graphical presentation of repetition kinetics of contact time on strontium adsorption.

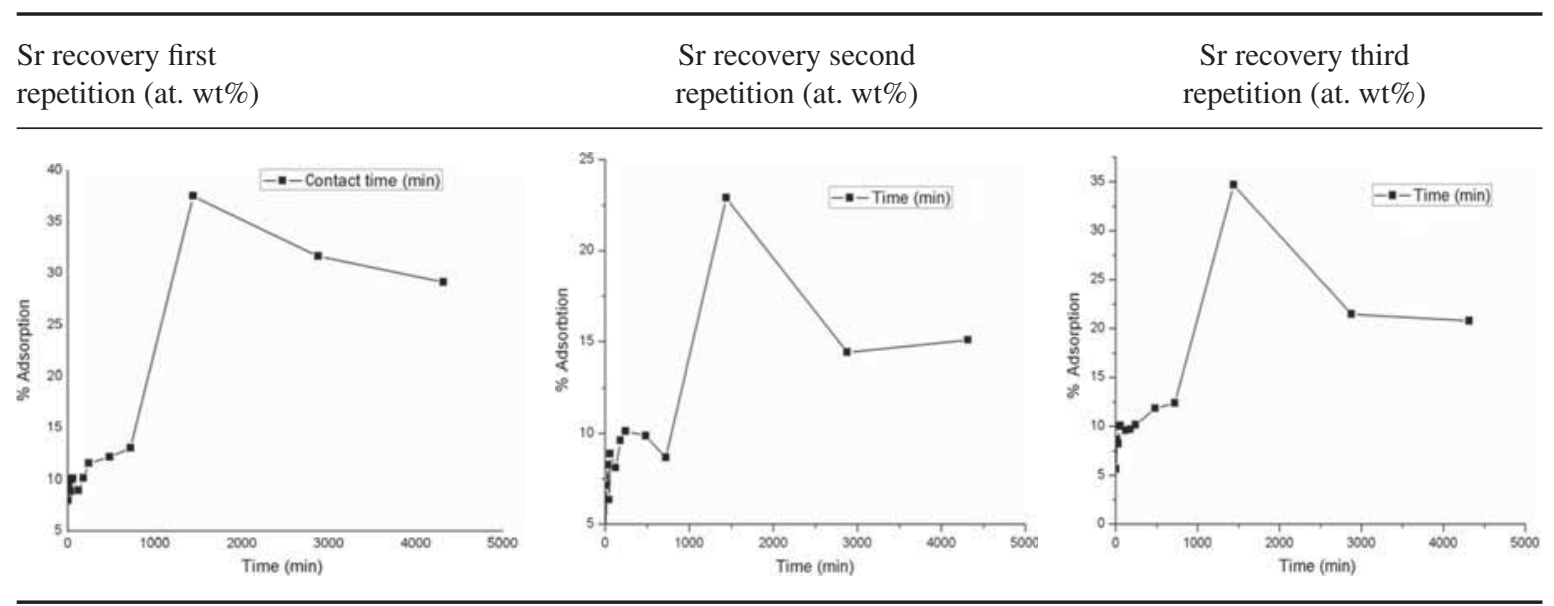




\subsection{Metal adsorption study of synthesized polymer}

The phosphonate-containing polymers have a wide range of applications. For example, these polymers are used as flame retardants and stabilizers for peroxides. One of their important uses is in metal ion recovery. For an in-depth study of this application, the phosphonate-containing polymer

Table 7. Effect of polymer concentration on strontium adsorption.

\begin{tabular}{lccc}
\hline $\begin{array}{l}\text { Metal } \\
\text { concentration } \\
(\mathrm{ml})\end{array}$ & $\begin{array}{c}\text { Polymer } \\
\text { concentration } \\
(\mathrm{mg})\end{array}$ & $\begin{array}{c}\text { Sr adsorbed } \\
\text { byEDX } \\
\text { (at. wt\%) }\end{array}$ & $\begin{array}{c}\text { Sr \% } \\
\text { recovery } \\
\text { (at. wt\%) }\end{array}$ \\
\hline 1 & 005 & 2.57 & 04.12 \\
1 & 010 & 4.31 & 09.51 \\
1 & 015 & 3.98 & 11.19 \\
1 & 025 & 3.02 & 12.14 \\
1 & 035 & 2.15 & 11.23 \\
1 & 050 & 2.72 & 19.15 \\
1 & 100 & 2.81 & 36.78 \\
1 & 200 & 1.49 & 37.53 \\
\hline
\end{tabular}

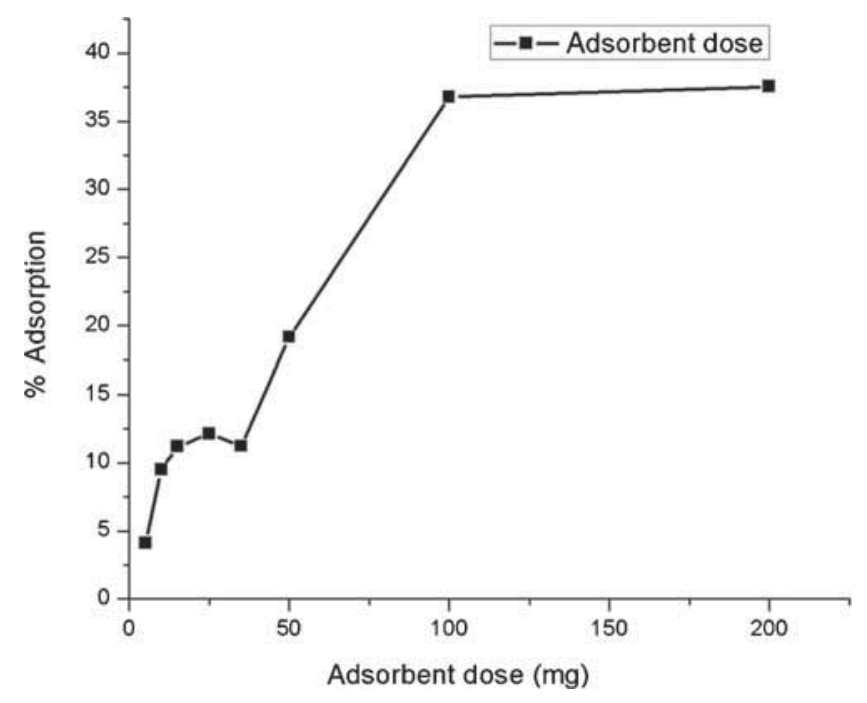

Figure 12. Effect of polymer concentration on strontium adsorption. was synthesized by hydrosilylation reaction using reactants diethylallylphosphonate and poly(methylhydro)siloxane in the presence of Speier's catalyst. The probable interaction mechanism of the polymer with the metal is depicted in figure 9 [37]. Three repetition batch experiments of each were carried out for adsorption study.

3.6a Effect of $\mathrm{pH}$ : The effect of $\mathrm{pH}$ on strontium uptake capacity of the polymer was studied rigorously. Accordingly, buffer solutions of $\mathrm{pH} \mathrm{1,3,5}$ and 7 were prepared. The effect of $\mathrm{pH}$ on the strontium adsorption by the polymer is illustrated in figure 10, and the corresponding conditions are listed in table 1.

From the graph it can be seen that the maximum uptake of strontium takes place at $\mathrm{pH} 3$. Almost $50 \%$ adsorption of the metal ions took place at this $\mathrm{pH}$. Accordingly, further experiments were conducted using the metal stock solutions of $\mathrm{pH} 3$.

The comparative data of repetition experiments on the effect of $\mathrm{pH}$ on strontium adsorption are shown in tables 2 and 3.

The repetition study on the effect of $\mathrm{pH}$ on strontium adsorption confirms that the maximum strontium uptake was at $\mathrm{pH} 3$.

3.6b Effect of contact time: The effect of the contact time on strontium adsorption by the polymer was studied in the time range of 5-4320 min (figure 11). The corresponding results are presented in table 4 .

Figure 11 shows that the maximum strontium uptake takes place at the contact time of $1440 \mathrm{~min}$. It is also seen that the strontium uptake increases with contact time.

The comparative data of effect of contact time on strontium adsorption are shown in tables 5 and 6.

Repetition kinetics of contact time effect convey that maximum uptake was observed at $1440 \mathrm{~min}$. In the repetition experiments, adsorption of strontium was observed as 37, 22 and $34 \%$ for first, second and third repetition, respectively.

3.6c Effect of polymer concentration: The effect of polymer concentration on the strontium adsorption was investigated by varying the DMPP polymer dose from 5 to $200 \mathrm{mg}$. The results of this study are reported in table 7 .

Table 8. Effect of polymer concentration on strontium adsorption with respect to repetition.

\begin{tabular}{lcccc}
\hline $\begin{array}{l}\text { Metal } \\
\text { concentration } \\
(\mathrm{ml})\end{array}$ & $\begin{array}{c}\text { Polymer } \\
\text { concentration } \\
(\mathrm{mg})\end{array}$ & $\begin{array}{c}\text { Sr recovery } \\
\text { first repetition } \\
\text { (at.wt\%) }\end{array}$ & $\begin{array}{c}\text { Sr recovery } \\
\text { second repetition } \\
\text { (at. wt\%) }\end{array}$ & $\begin{array}{c}\text { Sr recovery } \\
\text { third repetition } \\
\text { (at. wt\%) }\end{array}$ \\
\hline 1 & 005 & 04.12 & 05.63 & 03.72 \\
1 & 010 & 09.51 & 08.91 & 09.41 \\
1 & 015 & 11.19 & 10.33 & 09.88 \\
1 & 025 & 12.14 & 12.79 & 09.73 \\
1 & 035 & 11.23 & 15.54 & 13.65 \\
1 & 050 & 19.15 & 25.89 & 28.95 \\
1 & 100 & 36.78 & 24.38 & 31.72 \\
1 & 200 & 37.53 & 25.21 & 18.55 \\
\hline
\end{tabular}


Table 9. Graphical presentation of repetition kinetics of polymer concentration on strontium adsorption.

Sr recovery first
repetition (at. wt $\%$ )

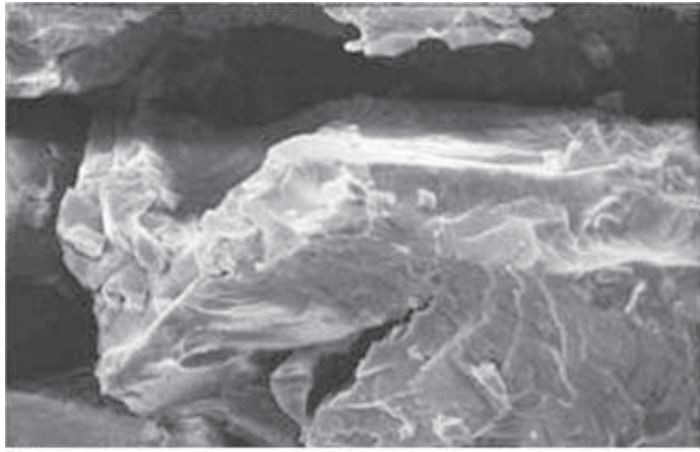

(a)

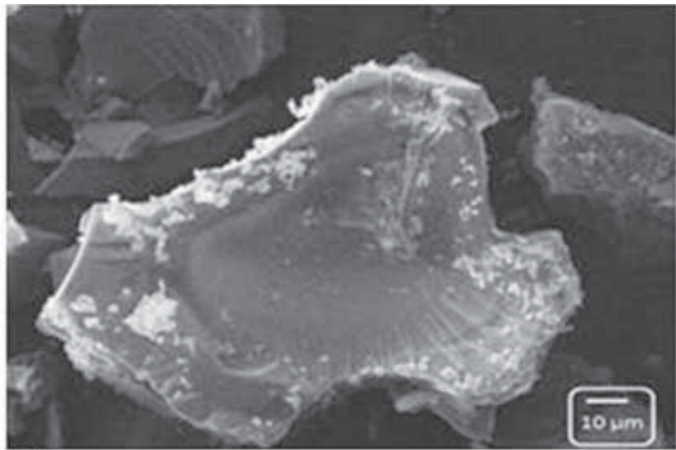

(b)

Figure 13. SEM images of (a) polymer without metal and (b) polymer with strontium metal.

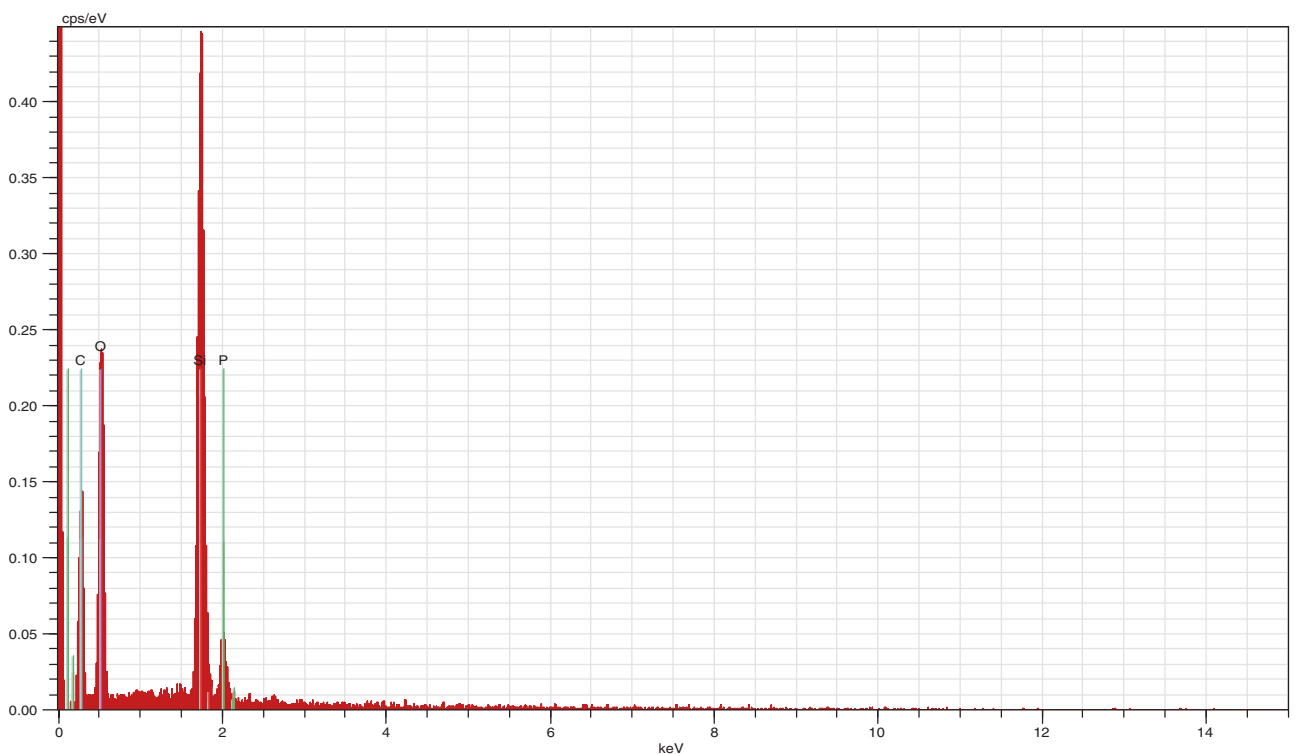

Figure 14. EDS of polymer without strontium metal. 


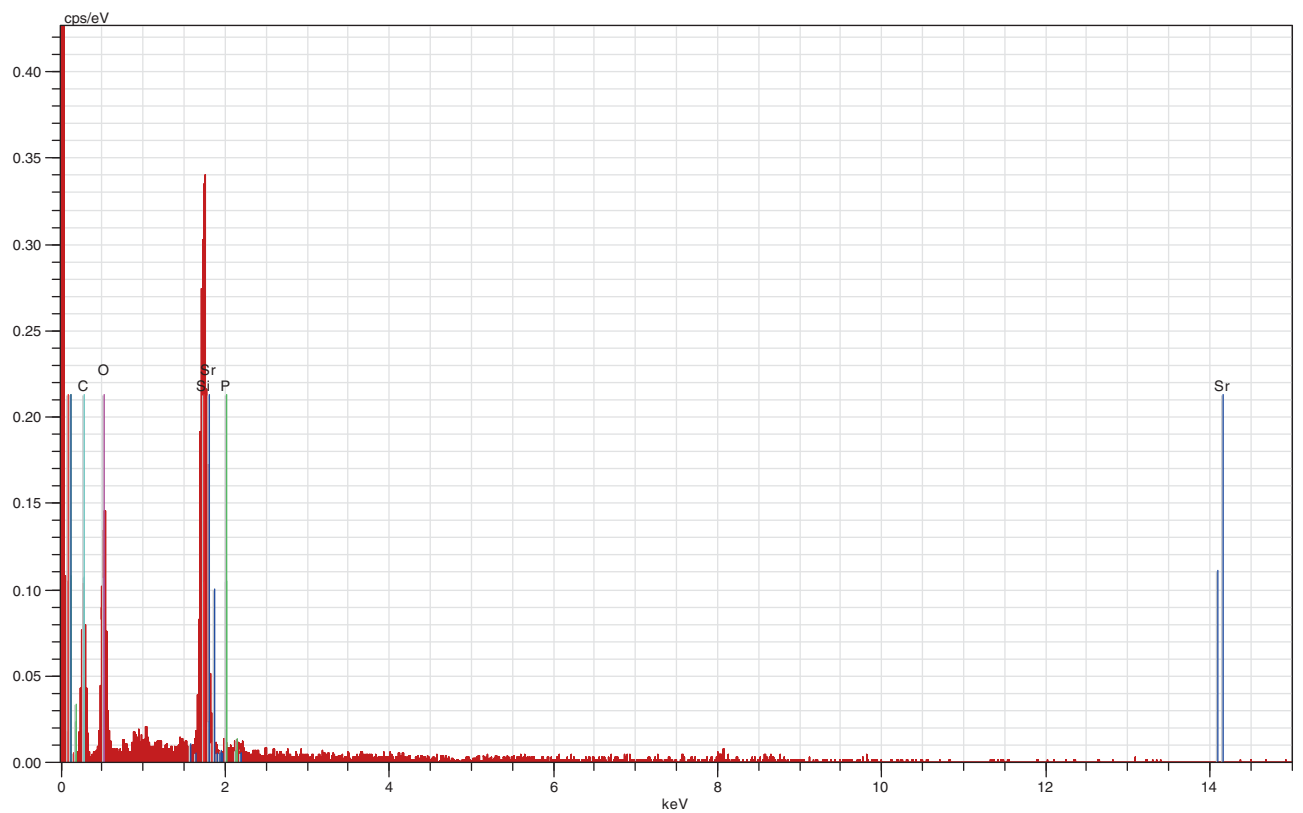

Figure 15. EDS of polymer with strontium metal.

Table 10. Langmuir adsorption equilibrium experimental data of Sr(II) onto DMPP polymer.

\begin{tabular}{lccc}
\hline $\begin{array}{l}\text { Contact } \\
\text { time }(\mathrm{min})\end{array}$ & $C_{\mathrm{e}}\left(\mathrm{mg} \mathrm{l}^{-1}\right)$ & $q_{\mathrm{e}}\left(\mathrm{mg} \mathrm{g}^{-1}\right)$ & $C_{\mathrm{e}} / q_{\mathrm{e}}$ \\
\hline 0005 & 1.9046 & 0.1653 & 11.5156 \\
0015 & 1.8750 & 0.1949 & 09.6157 \\
0030 & 1.8876 & 0.1823 & 10.3507 \\
0045 & 1.8627 & 0.2072 & 08.9900 \\
0060 & 1.8807 & 0.2092 & 08.8911 \\
0120 & 1.8847 & 0.1852 & 10.1731 \\
0180 & 1.8601 & 0.2098 & 08.8619 \\
0240 & 1.8302 & 0.2397 & 07.6355 \\
0480 & 1.8176 & 0.2523 & 07.2034 \\
0720 & 1.7992 & 0.2707 & 06.6452 \\
1440 & 1.2935 & 0.7764 & 01.6659 \\
2880 & 1.4144 & 0.6555 & 02.1575 \\
4320 & 1.4661 & 0.6038 & 02.4281 \\
\hline
\end{tabular}

Effect of polymer concentration on strontium adsorption is depicted in figure 12. It was observed that the percentage of strontium adsorption increases with increase in polymer concentration. The maximum strontium adsorption of $37.53 \%$ was observed at the polymer concentration of $200 \mathrm{mg}$, while a marginally lower uptake of $36.78 \%$ was seen for the $100 \mathrm{mg}$ polymer dose.

The comparative data of effect of polymer concentration on strontium adsorption are presented in tables 8 and 9.

Repetition experimental data of polymer concentration on strontium recovery confirmed that strontium recovery was $36.78,24.38$ and $31.72 \%$ at $100 \mathrm{mg}$ of polymer for first, second and third repetition, respectively.
Table 11. Freundlich adsorption equilibrium experimental data of $\mathrm{Sr}(\mathrm{II})$ onto DMPP polymer.

\begin{tabular}{lcccc}
$\begin{array}{l}\text { Contact } \\
\text { time }(\mathrm{min})\end{array}$ & $C_{\mathrm{e}}\left(\mathrm{mg} \mathrm{l}^{-1}\right)$ & $q_{\mathrm{e}}\left(\mathrm{mg} \mathrm{g}^{-1}\right)$ & $\log C_{\mathrm{e}}$ & $\log q_{\mathrm{e}}$ \\
\hline 0005 & 1.9046 & 0.1653 & 0.2798 & -0.7814 \\
0015 & 1.8750 & 0.1949 & 0.2730 & -0.7099 \\
0030 & 1.8876 & 0.1823 & 0.2759 & -0.7390 \\
0045 & 1.8627 & 0.2072 & 0.2701 & -0.6835 \\
0060 & 1.8807 & 0.2092 & 0.2696 & -0.6792 \\
0120 & 1.8847 & 0.1852 & 0.2752 & -0.7322 \\
0180 & 1.8601 & 0.2098 & 0.2695 & -0.6779 \\
0240 & 1.8302 & 0.2397 & 0.2625 & -0.6203 \\
0480 & 1.8176 & 0.2523 & 0.2595 & -0.5980 \\
0720 & 1.7992 & 0.270756 & 0.2550 & -0.5674 \\
1440 & 1.2935 & 0.7764 & 0.1117 & -0.1098 \\
2880 & 1.4144 & 0.6555 & 0.1505 & -0.1833 \\
4320 & 1.4661 & 0.6038 & 0.1661 & -0.2190 \\
\hline
\end{tabular}

\subsection{Scanning electron microscopy}

The SEM study of DMPP polymer was carried out with a view to examine its surface morphology and confirm the metal-ligand formation. Figure 13a and b, respectively, depicts the SEM-based scans of the polymer without and with the $\operatorname{Sr}(\mathrm{II})$ metal. Figure $13 \mathrm{~b}$ also reveals that the metal ions bind strongly to the DMPP polymer.

\subsection{Energy dispersive $X$-ray spectroscopy}

The adsorption of strontium metal ion on the DMPP polymer was monitored by EDS analysis. Figure 14 depicts the EDS 
of polymer without metal, while figure 15 shows the EDS of polymer with the $\mathrm{Sr}(\mathrm{II})$ metal.

\section{$3.9 \quad$ Surface area}

The surface area of DMPP polymer was $17.070 \mathrm{~m}^{2} \mathrm{~g}^{-1}$. Our synthesized polymer was a film, but not in a beaded form. Polymer was not porous, its functional groups play an important role in metal chelation.

\subsection{Adsorption isotherm study}

The study of isotherms provides important information regarding the interactions between an adsorbate and the adsorbent. In the present study, isotherm models were developed to gain an insight into the relationship between the concentration of $\mathrm{Sr}$ (II) in solution and the amount of $\mathrm{Sr}$ (II) adsorbed on the solid (polymer) phase when both phases are in equilibrium. Specifically, equilibrium adsorption data were fitted using the Langmuir, Freundlich, pseudo-first-order, and pseudosecond-order isotherm models. The adsorption of $\mathrm{Sr}(\mathrm{II})$ was performed by dissolving $5 \mathrm{mg}$ of sorbent in $1 \mathrm{ml}$ of $\mathrm{Sr}$ (II) solution at room temperature and $\mathrm{pH} 3$. The stated isotherm models are described below in greater details.

Table 12. Pseudo-first-order equilibrium experimental data of $\mathrm{Sr}(\mathrm{II})$ onto DMPP polymer.

\begin{tabular}{lc}
\hline Contact time (min) & $\log \left(q_{\mathrm{e}}-q_{\mathrm{t}}\right)$ \\
\hline 005 & -0.2139 \\
015 & -0.2354 \\
030 & -0.2261 \\
045 & -0.2446 \\
060 & -0.2462 \\
120 & -0.2282 \\
180 & -0.2467 \\
240 & -0.2702 \\
480 & -0.2805 \\
720 & -0.2961 \\
\hline
\end{tabular}

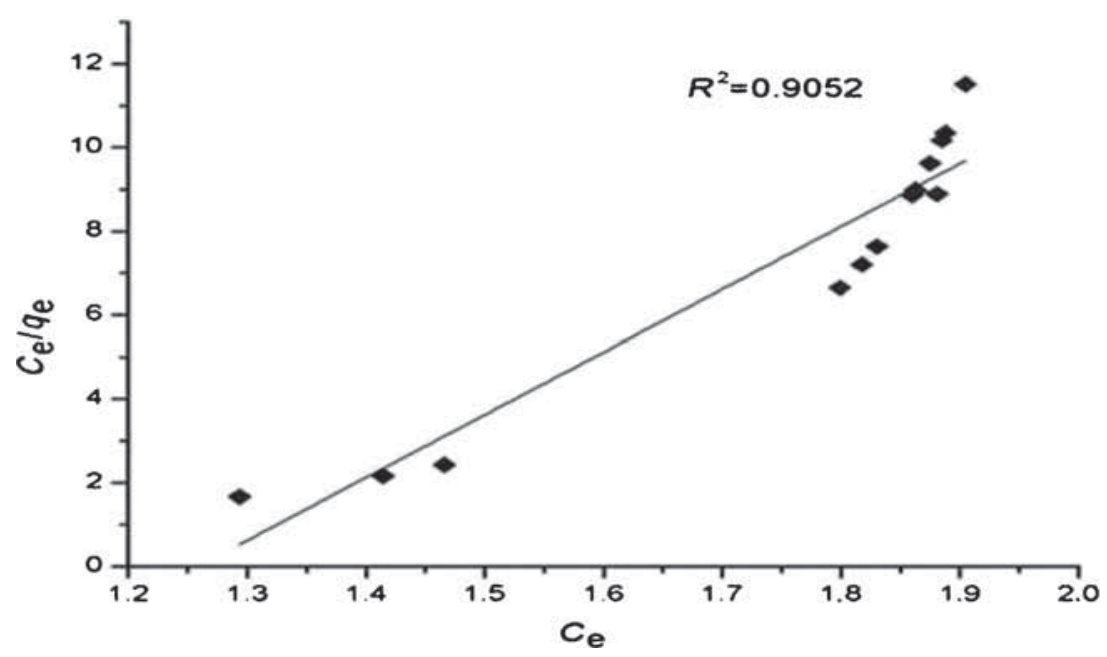

Figure 16. Langmuir adsorption isotherm of DMPP polymer.

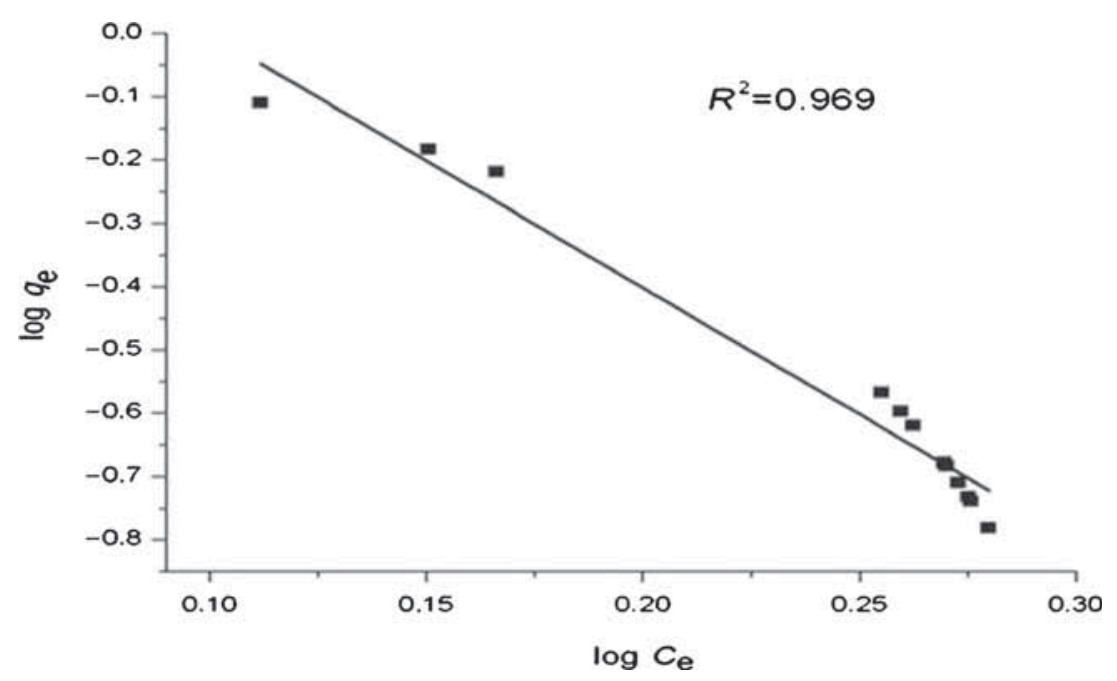

Figure 17. Freundlich adsorption isotherm of DMPP polymer. 


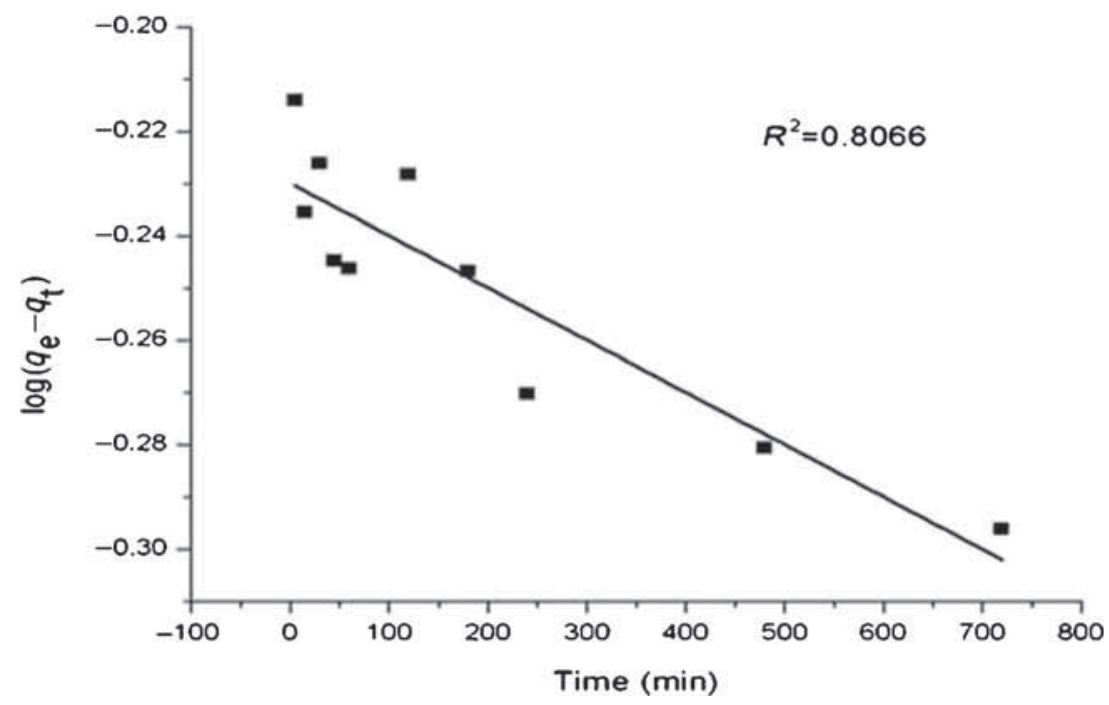

Figure 18. Pseudo-first-order kinetics of DMPP polymer.

Table 13. Pseudo-second-order equilibrium experimental data of $\mathrm{Sr}(\mathrm{II})$ onto DMPP polymer.

\begin{tabular}{lr}
\hline Contact time $(\mathrm{min})$ & \multicolumn{1}{c}{$t / q_{\mathrm{t}}$} \\
\hline 0005 & 030.2310 \\
0015 & 0076.9254 \\
0030 & 0164.5034 \\
0045 & 0217.1741 \\
0060 & 0286.7013 \\
0120 & 0647.7208 \\
0180 & 0857.5593 \\
0240 & 1001.2270 \\
0480 & 1902.2480 \\
0720 & 2659.2210 \\
1440 & 1854.5780 \\
2880 & 4393.1300 \\
4320 & 7154.4620 \\
\hline
\end{tabular}

3.10a Langmuir and Freundlich adsorption isotherm models: The Langmuir isotherm model is valid for monolayer adsorption onto the surface containing a finite number of identical sorption sites; this model is given as:

$$
\frac{C_{\mathrm{e}}}{q_{\mathrm{e}}}=\frac{1}{Q_{0} b}+\frac{C_{\mathrm{e}}}{Q_{0}},
$$

where $C_{\mathrm{e}}$ is the equilibrium concentration $\left(\mathrm{mg} \mathrm{l}^{-1}\right), q_{\mathrm{e}}$ the amount of $\mathrm{Sr}$ (II) adsorbed per gram at equilibrium $\left(\mathrm{mg} \mathrm{g}^{-1}\right)$, and $Q_{0}\left(\mathrm{mg} \mathrm{l}^{-1}\right)$ and $b$ (adsorbent per $\mathrm{mg}$ of adsorbate) are the Langmuir constants related to the adsorption capacity and energy of adsorption, respectively.

The linear Freundlich adsorption isotherm equation is given below

$$
\log q_{\mathrm{e}}=\log K_{\mathrm{f}}+\frac{1}{n} \log C_{\mathrm{e}},
$$

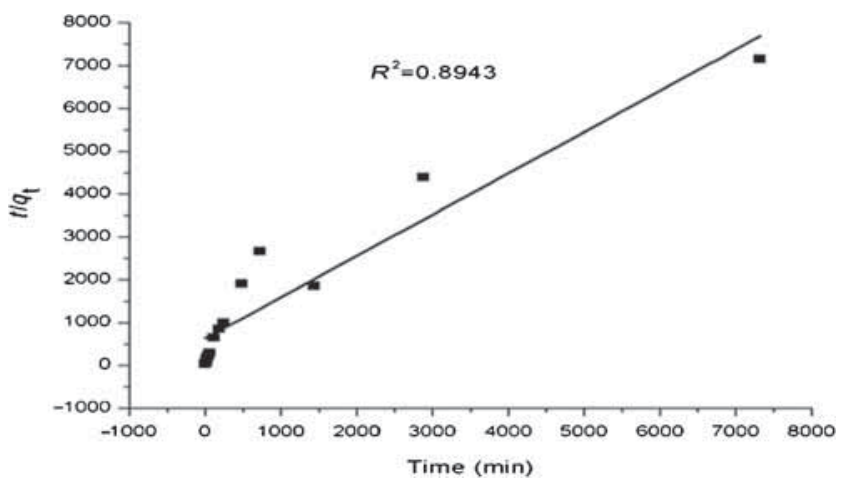

Figure 19. Pseudo-second-order kinetics of DMPP polymer.

where $C_{\mathrm{e}}$ is the residual concentration of $\mathrm{Sr}(\mathrm{II})$ in solution $\left(\mathrm{mg}^{-1}\right), K_{\mathrm{f}}$ a constant which measures adsorption capacity and $1 / n$ a measure of the adsorption intensity.

The adsorption data pertaining to Langmuir and Freundlich adsorption isotherms are given in tables 10 and 11, respectively; figures 16 and 17 show the adsorption equilibrium data fitted to the Langmuir and Freundlich isotherm expressions, respectively. From these plots and the corresponding $R^{2}$ values, it is seen that the Freundlich adsorption isotherm (variance, $R^{2}=0.969$ ) fits the adsorption data better than the Langmuir adsorption isotherm $\left(R^{2}=0.9052\right)$.

\subsection{0b Pseudo-first-order and pseudo-second-order kinetic} models:

Pseudo-first-order model: The pseudo-first-order model assumes that the rate of change of solute uptake with time is directly proportional to the difference in the saturation concentration and the amount of solid uptake with time:

$$
\operatorname{In}\left(q_{\mathrm{e}}-q_{\mathrm{t}}\right)=\operatorname{In} q_{\mathrm{e}}-k_{1} t,
$$


where $q_{\mathrm{e}}$ and $q_{\mathrm{t}}$ are the amounts of metal adsorbed per unit mass of the adsorbent $\left(\mathrm{mg} \mathrm{g}^{-1}\right)$ at equilibrium time, and any time $t$, respectively, and $k_{1}$ is the rate constant of adsorption $\left(\min ^{-1}\right)$. When $\ln \left(q_{\mathrm{e}}-q_{\mathrm{t}}\right)$ is plotted against time, a straight line should be obtained with a slope of $k_{1}$, if the first-order kinetics is obeyed.

The pseudo-first-order equilibrium experimental data of $\mathrm{Sr}$ (II) onto DMPP polymer is presented in table 12, and the pseudo-first-order kinetics of DMPP polymer is depicted in figure 18.

Pseudo-second-order model: The pseudo-second-order model as developed by Ho and McKay [38] has the following form:

$$
t / q_{\mathrm{t}}=t / q_{\mathrm{e}}+1 /\left(k_{2} q_{\mathrm{e}}^{2}\right)
$$

where $k_{2}$ is the rate constant of the pseudo-second-order equation $\left(\mathrm{g} \mathrm{mg}^{-1} \mathrm{~min}^{-1}\right)$. A plot of $t / q_{\mathrm{t}} v s$. time $(t)$ should yield a linear trend with the slope of $1 / q_{\mathrm{e}}$ and an intercept of $1 /\left(k_{2} q_{\mathrm{e}}^{2}\right)$, if the second-order model fits the adsorption data. The pseudo-second-order equilibrium experimental data of $\mathrm{Sr}$ (II) onto DMPP polymer are presented in table 13 , and the corresponding plot of the adsorption kinetics of the polymer is presented in figure 19.

A comparison of the $R^{2}$ magnitudes in respect of the four isotherm models, namely Langmuir, Freundlich, pseudo-first and pseudo-second order reveals that the model Freundlich's fits the adsorption data with best accuracy $\left(R^{2}=0.969\right)$. It was found that application of pseudo-second-order kinetics provide better correlation coefficient of experimental data than the pseudo-first-order model for adsorption of $\mathrm{Sr}(\mathrm{II})$ onto DMPP polymer.

\section{Conclusion}

A novel DMPP polymer was prepared and characterized by IR, ${ }^{1} \mathrm{H}$, and ${ }^{31} \mathrm{P}$ NMR methods. The results obtained in this study show that the polymer can be considered as a potential adsorbent material for the removal of strontium ions from aqueous solutions. The chelating propensity of this material is due to the phosphonate group present in the polymer. It was also found that the $\mathrm{Sr}$ (II) uptake on the polymer is maximum at $\mathrm{pH} 3$ and it decreases with increase in $\mathrm{pH}$. The adsorbent dose curve conveys that maximum $\mathrm{Sr}$ (II) binding to the polymer occurs at the polymer concentration of $200 \mathrm{mg}$. The effect of contact time was also studied in the time duration of 5 to $4320 \mathrm{~min}$. It was observed that the adsorption kinetic is rapid and the equilibrium reaches close to $1440 \mathrm{~min}$. Finally, adsorption data were analysed using Langmuir, Freundlich, pseudo-first and pseudo-second-order isotherm models. It was noted in this modelling study that the Freundlich adsorption isotherm fits the adsorption data with an excellent accuracy and pseudo-second-order kinetic model shows good fitting to the experimental data. The results presented in this article clearly show that DMPP polymer is a good candidate for the removal of $\mathrm{Sr}$ (II) from aqueous solutions. Repetition batch adsorption study concludes that the higher adsorption for effect of $\mathrm{pH}$, effect of contact time and effect of polymer concentration takes place nearly at one equilibrium point.

\section{Acknowledgements}

We express our gratitude towards CSIR for the award of research fellowship (Fellowship Award No. 31/11(741)/ 2012-EMR-I). We would like to thank the Department of Science and Technology, New Delhi, India, for the financial support of this research under the Program No. SR/S3/ CE/0049/2010.

\section{References}

[1] Abdel Rahman R O, Ibrahium H A and Hung Y T 2011 Water 3551

[2] Efremenkov V M 1989 Bulletin 437

[3] Shawabkeh R A, Rockstraw D A and Bhoda R K 2002 Carbon 40781

[4] Franke V 2010 Scholarly Commons. 1

[5] Reddy A R and Reddy K H 2003 Proc. Ind. Acad. Sci. 115 155

[6] Adams U I, Abdullahi U, Grace A, Happiness U I and Vincent C U 2012 J. Env. Prot. 3288

[7] Ferdos K M, Edris B, Mahdi F and Samira A 2013 J. Chem. 20131

[8] Zamzam B, Gupta A K and Amit C 2014 IOSR J. Appl. Chem. 739

[9] Motaharah H and Saeedeh H 2014 Orient. J. Chem. 301753

[10] Bhattacharya A and Thyagarajan G 1981 Chem. Rev. 81415

[11] Barney R J, Richardson R M and Wiemer D F 2011 J. Org. Chem. 762875

[12] Boutevin B, Hamoul B and Parisi J P 1993 Polym. Bull. 30 243

[13] Brondino C, Boutevin B, Hervaud Y, Pelaprat N and Manseri A 1996 J. Fluorine Chem. 76193

[14] Katrizky A R, Pilarski B and Johnson J W 1990 Org. Pre. Proc. Int. 22209

[15] Christov V C 1998 Phos. Sulph. Sili. 13273

[16] Popa A, Davidescu M, Negrea P and Demadis K D 2008 Ind. Eng. Chem. Res. 472010

[17] Boutevin B, Hervaud Y and Pietrasanta Y 1984 Phos. Sulf. 28189

[18] Adelowo F E 2012 IJRRAS 12107

[19] Kedrowski A M S and Dougherty A D 2010 Org. Lett. 1

[20] Kopping B, Chatgilialoglu C, Zehnder M and Giese B 1992 J. Org. Chem. 573994

[21] Corma A, Arellano C G, Iglesias M and Sanchez F 2007 Angew. Chem. Int. Ed. 467820

[22] Sommer L H, Michael K W, Fujimoto H and Lyons J E 1967 J. Am. Chem. Soc. 891521

[23] Ying B, Jiajian P, Hu Y, Jiayun L, Guoqiao L and Xiaonian L 2012 Chin. J. Chem. Eng. 20246

[24] Miao Q J, Fang Z P and Cai G P 2003 Catal. Commun. 4637

[25] Kawanami Y and Yamamoto K 1995 Syn. Lett. 1232

[26] Mukabaniani O, Gurgenidze G, Khananashvili L and Meladze S 2003 J. Polym. Mater. 52861 
[27] Gerardus J J, Klok H A, Schwegler L, Frey H and Moller M 1995 Macromol. Chem. Phys. 196185

[28] Song Y S, Yoo B R, Lee G H and Jung N 1999 Organometallics 183109

[29] Ding L, Hayakawa T and Kakimoto M A 2007 Polym. J. 39 551

[30] Putzein S, Nuyken O and Kuhn F E 2010 Prog. Poly. Sci. 35 687

[31] Chung D W and Kim T G 2007 J. Ind. Eng. Chem. 13979

[32] Speier J L, Webster J A and Barnes G H 1957 J. Am. Chem. Soc. 79974
[33] Chalk A J and Harrod J F 1965 J. Am. Chem. Soc. 8716

[34] Marciniec B, Aciejewski H M, Fiedorow R and Kitynski D 2003 Appl. Organo. Chem. 17127

[35] Putzien S, Zuyken O and Kuhn F E 2010 Prog. Poly. Sci. 35687

[36] Adina N, Lavinia L, Mihaela C and Petru N 2013 IJCEA 4326

[37] Fukuda S, Iida H, Yueming Y, Xie Y and Chen W 2000 INIS Collection 321

[38] Ho Y S and McKay G 1999 Process Biochem. 34451 